NOTE

\title{
Surface water distribution of pico- and nanophytoplankton in relation to two distinctive water masses in the North Water, northern Baffin Bay, during fall
}

\author{
Behzad Mostajiri, ${ }^{1,}$, Michel Gosselin ${ }^{1}$, Yves Gratton ${ }^{2}$, Beatrice Booth ${ }^{3}$, Christophe Vasseur ${ }^{1}$ \\ Marie-Ève Garneau ${ }^{1}$, Éric Fouilland ${ }^{1}$, Francesca Vidussi ${ }^{1}$, Serge Demers ${ }^{1}$ \\ ${ }^{1}$ Institut des sciences de la mer de Rimouski (ISMER), Université du Québec à Rimouski, 310 Allée des Ursulines, Rimouski, \\ Québec G5L 3A1, Canada \\ ${ }^{2}$ Institut National de la Recherche Scientifique (INRS-Eau), 2800 rue Einstein, CP 7500, Sainte-Foy, Québec G1V 4C7, Canada \\ ${ }^{3}$ School of Oceanography, University of Washington, Seattle, Washington 98195, USA
}

\begin{abstract}
Distribution of pico- and nanophytoplankton in surface waters was investigated in relation to environmental factors at 10 stations in the North Water (NOW), northern Baffin Bay, and at 4 more southerly stations in Baffin Bay in fall 1999. Water temperature $(T)$, salinity $(S)$, dissolved inorganic nitrogen (DIN), phosphate concentrations and pico- and nanophytoplankton abundances were measured in the surface waters in the studied area. A clustering analysis was performed on these data and allows 2 major ecological regions to be distinguished. An eastern region was characterized by warmer, more saline, surface waters $\left(T>-0.04^{\circ} \mathrm{C}, 31.1<S<\right.$ 32.7 ) where the picophytoplankton (eukaryotic flagellates, prasinophyte) were more abundant (700 to 4000 cells ml-1). The distribution of picophytoplankton in the NOW was directly correlated with the surface water $T$ and $S$. Another region, the northwestern, was characterized by colder, less saline, surface waters $\left(T<-1.2^{\circ} \mathrm{C}, 29.3<S<31.0\right)$, can be divided into northern and western sub-regions. Nanophytoplankton (mostly diatoms) were more abundant (>3000 cells $\mathrm{ml}^{-1}$ ) in the northern sub-region and their distributions followed the change in DIN concentrations. DIN and phosphate concentrations were higher in the northern sub-region than in the eastern region and the western sub-region, although DIN and phosphate concentrations were low in the NOW, with values ranging from 0.1 to 1.0 and 0.09 to $0.69 \mu \mathrm{M}$, respectively. Based on these ecological results, it is hypothesized that a surface current flows northward along the western coast of Greenland in fall, bringing warm, more saline water to the eastern part of the NOW. In contrast, surface Arctic water (colder, less saline) coming from the Kane Basin flows southward along the western part of the NOW. These 2 distinct water masses, with their different physical and chemical characteristics, govern pico- and nanophytoplankton distributions in the NOW during the fall.
\end{abstract}

KEY WORDS: Picophytoplankton · Nanophytoplankton · Arctic Polynya $\cdot$ Water temperature $\cdot$ Dissolved inorganic nitrogen

Resale or republication not permitted

without written consent of the publisher

*Present address: CNRS, ERS 2011 'Ecosystèmes Lagunaires', Université Montpellier II, CP 093, Place E. Bataillon, 34095 Montpellier Cedex 5, France.

E-mail: bmostajir@crit.univ-montp2.fr
The coupling between distributions of organisms and their physical and chemical environment leads to an understanding of the eco-physiological requirements of these organisms. Pico- $(0.2$ to $2 \mu \mathrm{m})$ and nanophytoplankton $(2$ to $20 \mu \mathrm{m})$ are 2 major size classes of phytoplankton which play a substantial role in the marine microbial food web. Environmental control of picoand nanophytoplankton distributions has been less investigated in the Arctic ecosystems than elsewhere. In Arctic regions, polynyas are one of the most accessible and interesting areas for oceanographic studies. Polynyas are open water regions (or very lightly icecovered; Lewis et al. 1996) surrounded by sea ice. They have been referred to as the oases of the Arctic because of their high productivity. The largest polynya in the Canadian Arctic is the North Water (NOW: 75 to $79^{\circ} \mathrm{N}, 66$ to $80^{\circ} \mathrm{W}$ ) polynya of Smith Sound and the northwestern Baffin Bay. Most of the oceanographic expeditions in the NOW have aimed at explaining the mechanisms responsible for the formation and maintenance of the polynya (e.g. Muench 1971, Steffen 1985, Steffen \& Ohmura 1985, Addison 1987).

To our knowledge, there has been only 1 study which investigated simultaneously the physical, chemical and biological variables in the NOW polynya; this study was carried out over just 2 d in May 1991 (Lewis et al. 1996). To expand our understanding of this area, a multidisciplinary study, the International North Water Polynya Study (NOW program), was initiated in 1997. The present study was conducted during the last cruise of this program in the fall of 1999 and describes the surface water distributions of pico- and nanophytoplankton as derived from flow cytometer measurements in relation to surface water temperature, salinity and nutrient concentrations.

Materials and methods. Fig. 1 shows the study area and the stations sampled for physical variables during 


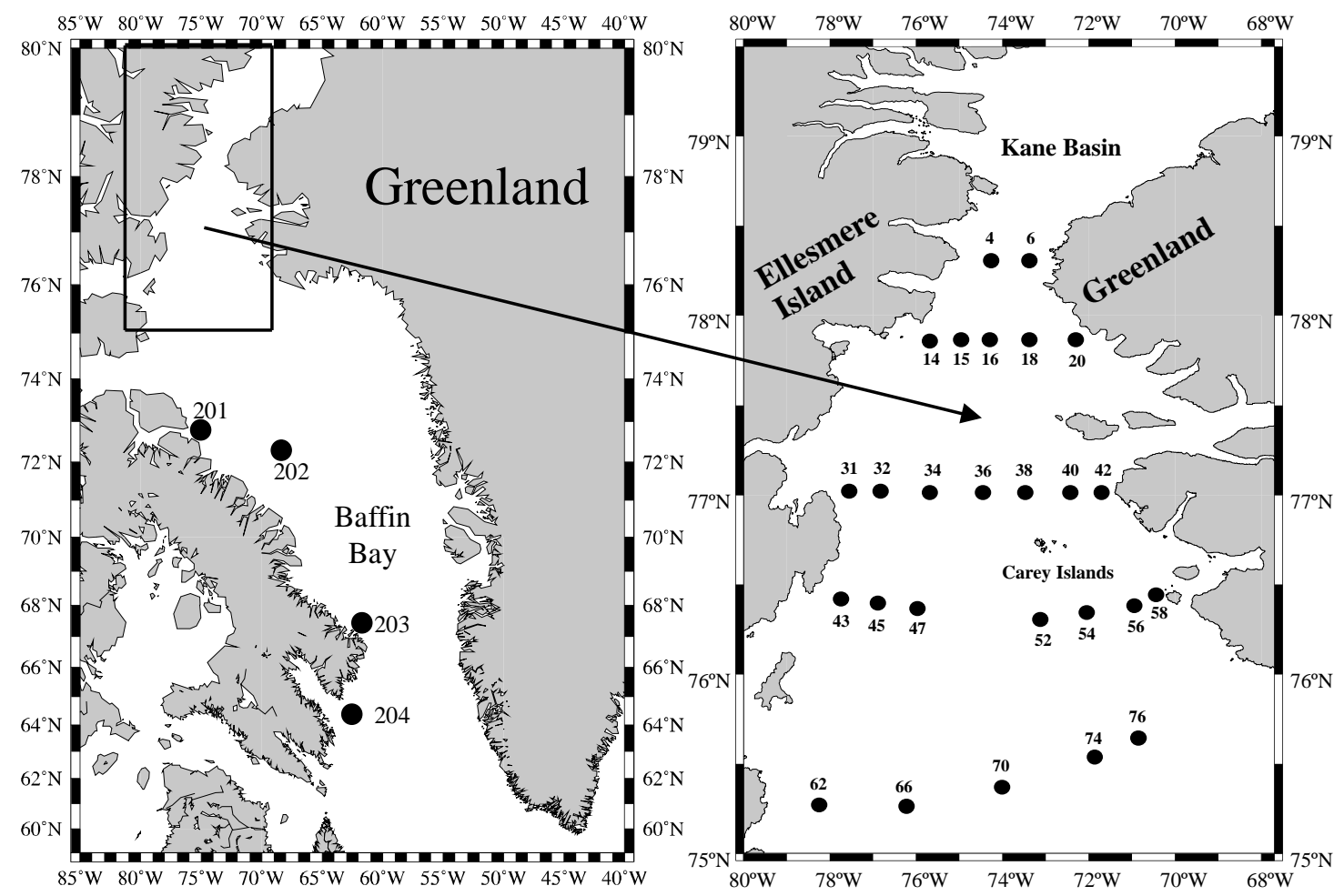

Fig. 1. Sampling area in the North Water (NOW) and in Baffin Bay. Temperature and salinity were measured at all stations. Samples for the determination of nutrients and phytoplankton abundance by flow cytometry were collected in surface waters at 10 stations in the NOW (Stns 15, 18, 31, 40, 42, 45, 54, 58, 66 and 76) and at 4 stations in Baffin Bay (Stns 201, 202, 203 and 204). Nutrient data are missing at Stn 202 in Baffin Bay. Pico- and nanophytoplankton abundances were also determined using a flow cytometer at 7 optical depths at Stns 15, 18 and 66 and at 3 optical depths at Stn 76. Samples for microscopic phytoplankton identification were collected at a single depth between 7 and $29 \mathrm{~m}$ at 7 stations in the NOW (Stns 18, 40, 45, 54, 76, 32 and 68; the location of the 2 latter stations, which are in close proximity to Stns 31 and 66, is not shown)

the 2nd leg of the 1999 NOW program (12 September to 5 October 1999: hereafter referred to as fall). Samples were collected with a rosette sampler (General Oceanics, Inc.) equipped with $10 \mathrm{l}$ water bottles (Brooke Ocean Technology Limited, Dartmouth, Nova Scotia) and a CTD (ICTD, Falmouth Scientific, British Columbia) which simultaneously measured salinity, temperature and depth.

Temperatures and salinity were measured in the water column at 26 stations in the NOW and at 4 more southerly stations in Baffin Bay (Fig. 1). In the present study, only surface water ( 0 to $2 \mathrm{~m}$ ) data are presented. Surface water temperature and salinity are the mean values of several measurements (maximum of 12) from the same cast.

For the determination of dissolved inorganic nutrient concentrations, surface water (0 to $2 \mathrm{~m}$ ) samples were collected at 10 stations in the NOW and at 3 stations in Baffin Bay (Fig. 1). Samples were filtered through precombusted $\left(500^{\circ} \mathrm{C}\right.$ for $\left.5 \mathrm{~h}\right)$ Whatman GF/F filters and the filtrate was analyzed immediately for ammonium using the method of Solórzano (1969) as described by Parsons et al. (1984). The remainder of the filtrate was frozen at $-80^{\circ} \mathrm{C}$ for later determination (within $2 \mathrm{mo}$ ) of nitrate plus nitrite, nitrite and phosphate using a Technicon II Autoanalyzer (Strickland \& Parsons 1972).

Surface water (0 to $2 \mathrm{~m}$ ) samples for determining phytoplankton distribution were collected at 10 stations in the NOW and at 4 stations in Baffin Bay (Fig. 1). They were analyzed using a FACSORT Analyzer flow cytometer (Becton-Dickinson) fitted with a $488 \mathrm{~nm}$ laser. Occasionally, samples were also collected at 7 optical depths $(100,50,30,20,10,1$ and $0.1 \%$ surface irradiance) at Stns 15, 18 and 66 and at 3 first optical depths at Stn 76. The forward light scatter signals were calibrated on board the ship using Fluoresbrite beads (Polysciences, Inc.) of different sizes. For samples of the NOW, duplicates of $2 \mathrm{ml}$ fresh samples, after adding beads of 2 and $10 \mu \mathrm{m}$ as internal standards, were immediately analyzed. Samples from Baffin Bay and vertical profiles were analyzed singly. The location of beads permitted, first, the identification of the size range of phytoplanktonic populations and, second, the instrument performance to be continuously controlled during analyses. This produced homogenous and comparable data. The flow rate of the flow 

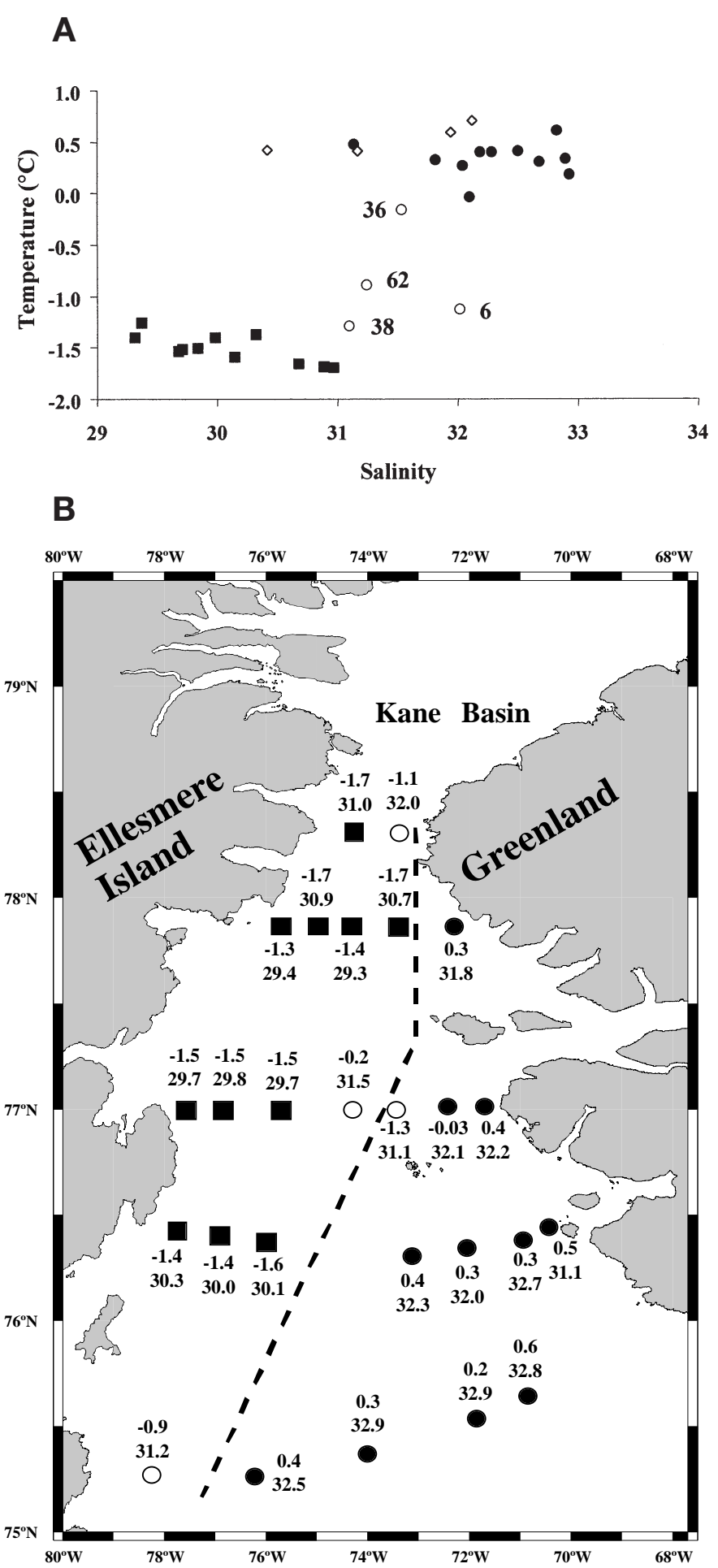

Fig. 2. (A) Temperature versus salinity of surface water in the NOW and Baffin Bay. ( $)$ Warm, more saline, surface waters; (ロ) cold, less saline, surface waters; (O) intermediate surface waters; ( $) 4$ surface waters of stations in Baffin Bay. (B) NOW surface water temperature and salinity map in fall 1999. Dashed lines, passing near the intermediate stations, are boundaries between the warm, more saline, surface waters and the cold, less saline, surface waters in the NOW

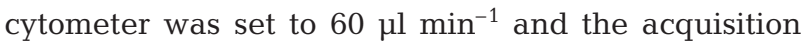
time was between 5 and $20 \mathrm{~min}$. The phytoplankton were detected using red fluorescence (>650 nm), which is attributed to chlorophyll (chl). To verify the presence of cyanobacteria, orange fluorescence (585 \pm $21 \mathrm{~nm})$, characteristic of phycoerythrin pigment, was also utilized. The data were logged using Cell Quest software and analyzed with Attractors software, both from Becton-Dickinson. Samples for phytoplankton microscopic identification were collected at 7 stations in the NOW (see legend of Fig. 1). They were stored and identified according to the protocol detailed by Booth (1993).

Before undertaking the different parametric statistical tests, the normality of distribution and the homogeneity of variance of each variable were verified with the normal probability plot of residuals and Bartlett's test, respectively (Sokal \& Rohlf 1981). When required, the data were transformed. To regroup stations with similar physical, chemical and biological characteristics, 2 clustering analyses were performed. First, the data collected at 10 stations in the NOW (i.e. water temperature, salinity, phosphate, dissolved inorganic nitrogen [DIN: sum of nitrate, nitrite and ammonium], pico- and nanophytoplankton abundances) were standardized. A complete linkage clustering of a matrix of Euclidean distances among the standardized data was then achieved according to Legendre \& Legendre (1984) using Statistica software (StatSoft, Tulsa, OK). Second, the same analysis described above was performed using the data collected at 3 stations in Baffin Bay (Stns 201, 203 and 204) as well as those from the NOW. For each variable, a 1-way analysis of variance (ANOVA) was performed to seek significant differences among groups of stations (or regions) in the studied area. The ANOVA was completed by a multiple comparison test of means (Tukey's Honestly Significant Difference test for unequal sample sizes). Spearman's rank correlations $\left(\mathrm{r}_{\mathrm{s}}\right)$ were also calculated to determine the relationships between the different variables measured at the 10 stations in the NOW.

Results. Surface water temperature and salinity in the NOW ranged from -1.69 to $0.60^{\circ} \mathrm{C}$ and 29.37 to 32.93, respectively. In Baffin Bay, they ranged from 0.41 to $0.70^{\circ} \mathrm{C}$ and 30.42 to 32.12 , respectively. Surface water temperature versus salinity are plotted in Fig. 2A for all stations. Two groups of stations in the NOW were distinguished: (1) stations with cold surface water $<-1.2^{\circ} \mathrm{C}$ and low salinity, varying from 29.3 to 31.0 , located on the Canadian side of the NOW, and (2) those with warm surface water $>-0.04^{\circ} \mathrm{C}$ and high salinity, ranging from 31.1 to 32.7 , located on the Greenlandic side of the NOW (Fig. 2A). Four stations (Stns 6, 36, 38 and 62) have intermediate temperature and salinity characteristics (Fig. 2A) and were close to 
the boundary between the warm, more saline, surface waters observed near the Greenland coast and the cold, less saline, surface waters observed along the Canadian coast (Fig. 2B). The Baffin Bay stations were characterized by warm, more saline, surface waters, much like the waters near Greenland in the NOW (Fig. 2A).

Nutrients were generally low in the surface waters of the NOW and in Baffin Bay (Table 1). Nitrate concentrations ranged from 0.03 to $0.72 \mu \mathrm{M}$, with relatively high values $(\geq 0.60 \mu \mathrm{M})$ measured in the northern part of the NOW (Stns 15 and 18) as well as on the Greenlandic side (Stns 42 and 76). Nitrate concentrations in Baffin Bay ranged from 0.15 to $0.70 \mu \mathrm{M}$ (Table 1). Nitrite concentrations had no consistent pattern and were very low (between 0.04 and $0.15 \mu \mathrm{M}$ ). Ammonium concentrations varied between undetectable levels and $0.20 \mu \mathrm{M}$ in the NOW and Baffin Bay. The highest DIN concentrations were found in the northern part (Stn 15; Table 1) and near the Greenland coast (Stns 42 and 76). Phosphate concentrations in the surface water of the NOW and Baffin Bay ranged from $0.09 \mu \mathrm{M}$ (Stn 58) to $0.69 \mu \mathrm{M}$ (Stn 15). Molar DIN: $\mathrm{PO}_{4}$ ratios in the NOW and Baffin Bay were low, ranging from 0.33 to 5.33 (Table 1).

Picophytoplankton ranged in size from $<1$ to $2 \mu \mathrm{m}$. Their highest concentrations in the surface waters were observed in the eastern part of the NOW at Stns 76,40 and 66, with values of ca 4100, 1700 and 1100 cells $\mathrm{ml}^{-1}$, respectively (Table 1 , Fig. $3 \mathrm{~A}$ ). The lowest concentrations of picophytoplankton $\left(<100 \mathrm{cells} \mathrm{ml}^{-1}\right)$ were measured at Stns 31 and 45, which are located in the western part of the NOW (Table 1, Fig. 3A). In the surface waters of Baffin Bay, picophytoplankton con- centrations were generally higher than 1300 cells ml ${ }^{-1}$, with a lower value of 700 cells ml $^{-1}$ at Stn 201. Microscopic identifications revealed that the picophytoplankton were eukaryotes shaped like Micromonas, a prasinophyte alga. Indeed, HPLC pigment signatures of fractionated $(<5 \mu \mathrm{m})$ surface water collected at Stn 203, where the picophytoplankton were very abundant in fall 1999, were very similar to those of Micromonas sp. isolated in the NOW in June 1998 (F. Vidussi \& C. Lovejoy unpubl. data). It should be noted that cyanobacteria were not observed in the surface waters of the studied area in fall 1999.

Nanophytoplankton abundances were maximum in the northern part of the NOW (Stns 15 and 18), with concentrations of $>3000$ cells ml $^{-1}$ (Table 1, Fig. 3B). Nanophytoplankton abundances in the central part of the NOW (Stns 40, 45 and 54) varied between 1000 and 1200 cells ml$^{-1}$. At the same latitudes near the coast of Greenland (Stns 42 and 58), nanophytoplankton abun-

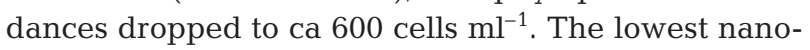
phytoplankton concentrations were observed at Stns 66 (ca 400 cells ml-1) and $76\left(450\right.$ cells ml $\left.{ }^{-1}\right)$ in the southern part of the NOW and at Stn $31\left(300\right.$ cells ml$^{-1}$ ) at $77^{\circ} \mathrm{N}$ near the Canadian coast (Fig. 3B). In the surface waters of Baffin Bay, nanophytoplankton abundances varied between 100 and 1000 cells ml ${ }^{-1}$. The nanophytoplankton community comprised mostly centric Bacillariophyceae (Chaetoceros socialis, $10 \times 5 \mu \mathrm{m}$; C. hyalochaete, $8 \times 7 \mu \mathrm{m}$; and Thalassiosira sp., ca $12 \mu \mathrm{m})$. The other groups were Prymnesiophyceae, Dinophyceae (Gymnodinium spp., peanut shaped, 5 to $10 \mu \mathrm{m}_{i}$ Gymnodinium spp., $<15 \mu \mathrm{m}$; and another species of 15 to $20 \mu \mathrm{m}$ ) and Dictyochophyceae (Dictyocha speculum, ca $18 \mu \mathrm{m})$.

Table 1. Mean (range of the observations) abundances of pico- and nanophytoplankton (cells $\mathrm{m} \mathrm{l}^{-1}$ ), nutrient concentrations $(\mu \mathrm{M})$ and dissolved inorganic nitrogen:phosphate ratio (mol:mol) in the surface waters of the North Water (NOW) and Baffin Bay in the fall of 1999. na: not analysed; nd: not detected

\begin{tabular}{|c|c|c|c|c|c|c|c|c|}
\hline Stn & Picophyto. & Nanophyto. & $\mathrm{NO}_{3}$ & $\mathrm{NO}_{2}$ & $\mathrm{NH}_{4}$ & DIN & $\mathrm{PO}_{4}$ & DIN: $\mathrm{PO}_{4}$ \\
\hline \multicolumn{9}{|c|}{ NOW } \\
\hline 15 & $290(94)$ & $3080(57)$ & 0.72 & 0.05 & 0.20 & 0.97 & 0.69 & 1.41 \\
\hline 18 & $278(76)$ & 3009 (181) & 0.60 & 0.06 & 0.03 & 0.69 & 0.63 & 1.10 \\
\hline 31 & $18(7)$ & $272(93)$ & 0.03 & 0.06 & nd & 0.09 & 0.27 & 0.33 \\
\hline 40 & $1671(102)$ & $1010(246)$ & 0.19 & 0.08 & nd & 0.27 & 0.40 & 0.68 \\
\hline 42 & 1007 (16) & $571(51)$ & 0.69 & 0.06 & 0.13 & 0.88 & 0.17 & 5.18 \\
\hline 45 & $58(22)$ & 962 (164) & 0.32 & 0.05 & nd & 0.37 & 0.67 & 0.55 \\
\hline 54 & $832(532)$ & $1190(308)$ & 0.11 & 0.15 & nd & 0.26 & 0.40 & 0.65 \\
\hline 58 & 709 (136) & 645 (333) & 0.28 & 0.06 & 0.14 & 0.48 & 0.09 & 5.33 \\
\hline 66 & $1088(69)$ & $418(23)$ & 0.35 & 0.04 & 0.01 & 0.40 & 0.39 & 1.03 \\
\hline 76 & 4067 (80) & 447 (14) & 0.65 & 0.07 & nd & 0.72 & 0.31 & 2.32 \\
\hline \multicolumn{9}{|c|}{ Baffin Bay } \\
\hline 201 & 682 & 127 & 0.29 & 0.06 & nd & 0.35 & 0.43 & 0.81 \\
\hline 202 & 3833 & 513 & na & na & na & na & na & na \\
\hline 203 & 1310 & 373 & 0.15 & 0.08 & 0.24 & 0.47 & 0.44 & 1.07 \\
\hline 204 & 2061 & 959 & 0.70 & 0.06 & 0.02 & 0.78 & 0.54 & 1.44 \\
\hline
\end{tabular}


The complete linkage clustering led to separation of 2 major ecological regions within the NOW: (1) an eastern region composed of Stns 40,42, 54, 58, 66 and 76; and (2) a northwestern region consisting of Stns 15, 18, 31 and 45. The northwestern region can be divided into 2 sub-regions: northern and western. The physical, chemical and biological characteristics of the different regions in the NOW are presented in Table 2 . The eastern region had significantly higher surface water temperature and salinity than the northern and western sub-regions. In addition, this region showed significantly higher picophytoplankton abundance than the western sub-region, and lower concentrations of nanophytoplankton and DIN than the northern sub-region. Finally, the western sub-region had significantly lower nanophytoplankton concentrations than the northern sub-region. Another cluster analysis using the data from Baffin Bay and the NOW allowed all the stations from Baffin Bay to be included with those of the eastern region of the NOW previously described. According to correlation analysis, in the NOW picophytoplankton abundance was directly correlated with water temperature and salinity while nanophytoplankton abundance was directly correlated with DIN concentration (Table 3).

Discussion. Simultaneous investigation of physical, chemical and biological variables led to the separation of 2 major ecological regions in the NOW during fall. The northwestern region was characterized by cold $\left(<-1.2^{\circ} \mathrm{C}\right)$ and less saline (between 29.3 and 31.0) surface water, whereas the eastern region was characterized by warm $\left(>-0.04^{\circ} \mathrm{C}\right)$ and more saline (between 31.1 and 32.7 ) surface waters (Fig. 2). These results are in agreement with earlier studies showing the presence of warm water along the Greenland coast (Steffen 1985, Melling et al. in press). The frontier between the northwestern and eastern regions passing near Stns 36 and 38 (Fig. 2B) corresponds more or less to the boundary which had been determined in a previous study from the abundances of large phytoplankton taxa in the NOW in May 1991 (Lewis et al. 1996, their Fig. 2).
A

Cells $<2 \mu \mathrm{m} \mathrm{mL}^{-1}$
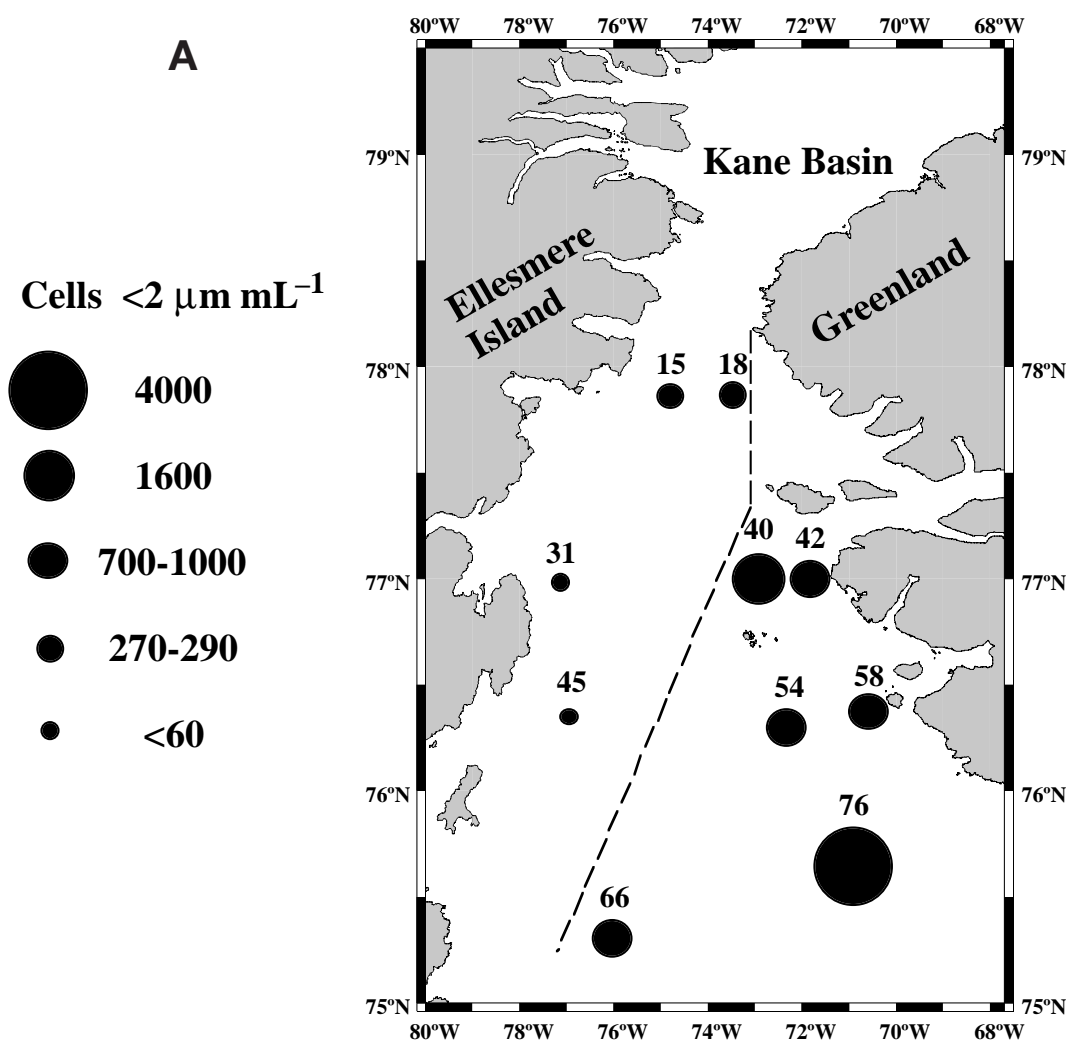

B

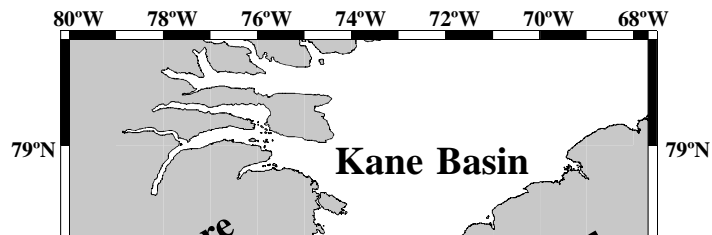

Cells $2-20 \mu \mathrm{m} \mathrm{mL}^{-1}$
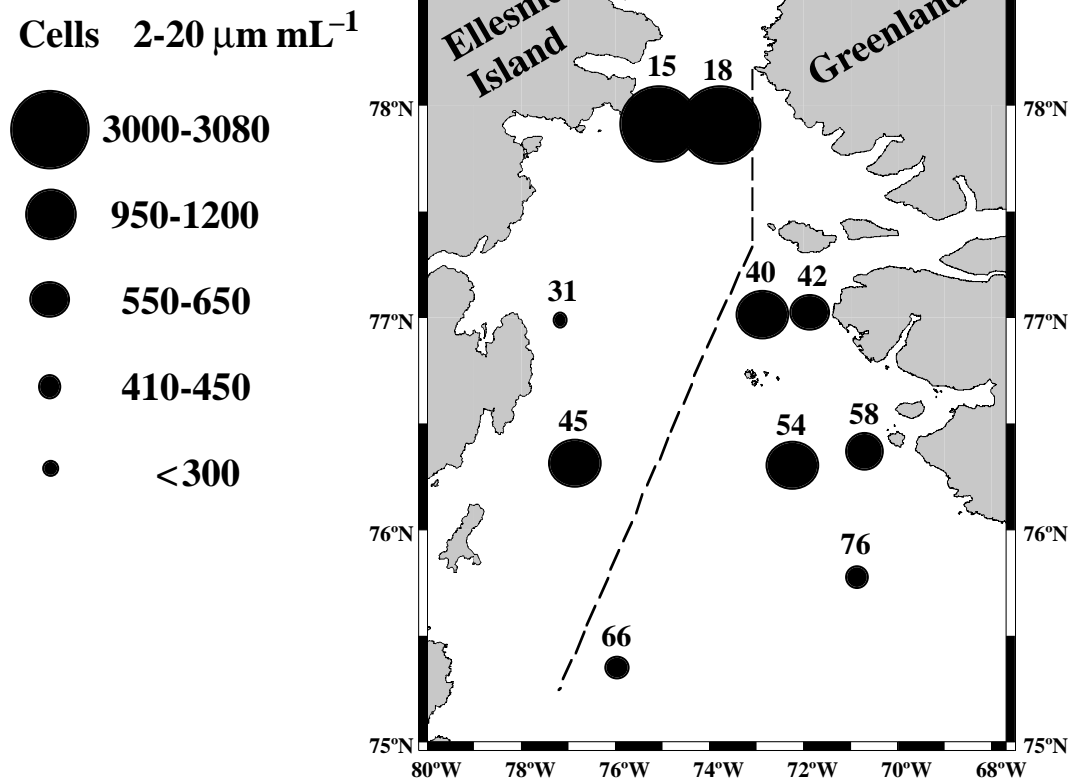

Fig. 3. Surface water distributions of (A) picophytoplankton, and (B) nanophytoplankton in the NOW in fall 1999. Dashed lines indicate the boundary between cold, less saline and warm, more saline, surface waters 
During this study, the contribution of phytoplankton $<5 \mu \mathrm{m}$ to the total chl a concentration $(>0.7 \mu \mathrm{m})$ in the surface waters of the NOW varied from 16 to $37 \%$ in the eastern region, from 12 to $20 \%$ in the western subregion and from 10 to $13 \%$ in the northern sub-region (B. Klein pers. comm.). In terms of cell number, picophytoplankton were, on average, 6 and 41 times more abundant in the eastern region than in the northern and western sub-regions, respectively (Table 2). They were generally more abundant in the surface waters than in the lower part of the euphotic layer (data not shown). The strong direct relationships between the horizontal abundance of picophytoplankton and the surface water temperature and salinity in this study (Table 3) show a close association of picophytoplankton with the warm and saline surface waters of the NOW in fall. However, in summer 1998, picophytoplankton bloomed (>3000 cells $\mathrm{ml}^{-1}$ ) at Stns 54, 58 and 68 (near Stn 66; Fig. 1) at depths ranging between 6 and $50 \mathrm{~m}$ in cold water $\left(-0.8^{\circ} \mathrm{C}>T>-1.7^{\circ} \mathrm{C}\right)$ and high salinity $(32<S<33.5)$ (B. Booth unpubl. data). In the NOW and Baffin Bay, picophytoplankton were dominated by a prasinophyte alga, presumably Micromonas sp. This species is probably the most common phototrophic flagellate of Arctic seas. For example, $M$. pusilla $<2 \mu \mathrm{m}$ was observed at high concentrations (132 000 cells ml $^{-1}$ ) in the Northeast Water (NEW) polynya, located on the continental shelf off NE Greenland, during the summer 1993 (Booth \& Smith 1997). In both the NEW polynya and the NOW, this picophytoplankter was found in ice-free areas at a period when nitrate was at a low concentration (i.e. $0.83 \mu \mathrm{M}$ in the
NEW polynya and ca 0.1 to $0.7 \mu \mathrm{M}$ in the NOW). Picophytoplankton, hypothetically $M$. pusilla, were also found in summer 1994 in ice-covered waters of the Pacific side of Arctic Ocean at concentrations between ca 1300 and 10000 cells ml ${ }^{-1}$ (Booth \& Horner 1997). Results of the 1997-1998 SHEBA (Surface Heat Budget of the Arctic Ocean) expedition in the permanently icecovered Arctic Ocean ( 75 to $80^{\circ} \mathrm{N}, 143$ to $166^{\circ} \mathrm{W}$ ) showed that Micromonas sp. reached a maximum abundance of 28000 cells ml ${ }^{-1}$ during the initial spring bloom and were present at an abundance of 1000 to 10000 cells ml-1 in the upper $40 \mathrm{~m}$ during the rest of the growing season (Sherr et al. unpubl. data). This picophytoplankter, therefore, is ubiquitous and abundant in Arctic systems.

In contrast to picophytoplankton, nanophytoplankton were, on average, 4 times more abundant in the cold, less saline, surface waters of the northern subregion than in the eastern region (Table 2). They were also more homogeneously distributed in the euphotic layer than picophytoplankton (data not shown). The surface waters of the northern sub-region contained higher concentrations of DIN and phosphate than the eastern region and the western sub-region. In the sur-

Table 3. Spearman's rank correlation coefficients between physical, chemical and biological variables studied in surface waters of the NOW in fall 1999 (number of observations, $n=10$ ). Bold values are significant at $p \leq 0.05$ level

\begin{tabular}{|c|c|c|c|c|c|c|c|c|}
\hline & Salinity & $\mathrm{NO}_{3}$ & $\mathrm{NO}_{2}$ & $\mathrm{NH}_{4}$ & DIN & $\mathrm{PO}_{4}$ & $\begin{array}{l}\text { Picophytoplankton } \\
\text { abundance }\end{array}$ & $\begin{array}{c}\text { Nanophytoplankton } \\
\text { abundance }\end{array}$ \\
\hline Water temperature & 0.76 & 0.02 & 0.24 & 0.09 & -0.70 & 0.09 & 0.70 & -0.53 \\
\hline Salinity & & 0.35 & 0.22 & -0.06 & -0.32 & 0.33 & 0.96 & -0.24 \\
\hline $\mathrm{NO}_{3}$ & & & -0.41 & 0.61 & 0.21 & 0.96 & 0.23 & 0.24 \\
\hline $\mathrm{NO}_{2}$ & & & & -0.46 & -0.22 & -0.31 & 0.37 & 0.13 \\
\hline $\mathrm{NH}_{4}$ & & & & & -0.06 & 0.73 & -0.11 & 0.31 \\
\hline DIN & & & & & & 0.07 & -0.25 & 0.71 \\
\hline $\mathrm{PO}_{4}$ & & & & & & & 0.23 & 0.27 \\
\hline $\begin{array}{l}\text { Picophytoplankton } \\
\text { abundance }\end{array}$ & & & & & & & & -0.15 \\
\hline
\end{tabular}


face waters of the NOW, the horizontal distribution of nanophytoplankton followed the change in DIN concentrations (Table 3). This suggests that the availability of nutrient plays a greater role in the distribution of large algal cells in the NOW than do water temperature and salinity.

Nutrient availability often governs the extent and duration of phytoplankton blooms in coastal and oceanic waters. During the fall of 1999, the surface concentrations of DIN and phosphate were low in the NOW, with values ranging from 0.1 to 1.0 and 0.09 to $0.69 \mu \mathrm{M}$, respectively. These concentrations are much lower than the nitrate and phosphate concentrations of 3.7 to 10.8 and 0.5 to $1.4 \mu \mathrm{M}$, respectively, measured in the NOW at the beginning of the spring bloom in May 1991 (Lewis et al. 1996). In the present study, the DIN: $\mathrm{PO}_{4}$ molar ratios (Table 1) were always lower than the value of 16 of Redfield et al. (1963), which suggests possible deficiency in dissolved nitrogen relative to phosphorus. Since the surface waters of the northern sub-region contained, on average, more DIN and phosphate than those in the eastern region and western sub-region, respectively (Table 2), this can indicate that the Kane Basin located in the north of the studied area (Fig. 1) is a source of dissolved nutrients for the NOW. According to the nutrient enrichment in the northern sub-region and based on the cold, less saline characteristics of the northwestern region of the NOW, the surface water mass of this region, which contains very few picophytoplankton, could be considered as a tracer of Arctic water coming from the Kane Basin. This is in agreement with the surface water current in the NOW found by Muench (1971) and Bourke et al. (1989, their Fig. 4), among others. Despite the low water temperature, the input of new nutrients permits the growth and accumulation of large phytoplankton in the northern sub-region of the NOW in the fall. In the NOW, the concentrations of nitrate between 0.03 and $0.7 \mu \mathrm{M}$ (Table 1) are within the range of reported values for the affinity constant of large phytoplankton for nitrate in oceanic and coastal waters $\left(K_{\mathrm{s}}=0.01\right.$ to $\leq 2.0 \mu \mathrm{M}_{\text {; }}$ Eppley et al. 1969, Carpenter \& Guillard 1971, MacIsaac \& Dugdale 1972). It thus appears that the large phytoplankton had already reduced nitrate concentrations to levels that limited the abundances of these cells.

Baffin Bay surface waters, because of their similar biological and environmental characteristics, were grouped by cluster analysis within the eastern region of the NOW. The presence of more than 1000 picophytoplankton cells $\mathrm{ml}^{-1}$ in Baffin Bay surface waters with a temperature higher than $0.4^{\circ} \mathrm{C}$ demonstrates again that picophytoplankton develop to a greater extent in relatively warmer surface water in fall. This result also supports the hypothesis that picophytoplankton ob- served in the NOW in fall may originate from waters flowing from the south. Lewis et al. (1996) observed warm water between 250 and $350 \mathrm{~m}$ in May at their Stn $1\left(76^{\circ} 23^{\prime} \mathrm{N}, 71^{\circ} 29^{\prime} \mathrm{W}\right.$, near Stn 58 in the present study; Fig. 1). Based on the discovery of deep warm water in spring, Lewis et al. (1996) hypothesized that the West Greenland Current (WGC) moves north in winter and enters the NOW through the channel between the Carey Islands and the Greenland coast. They concluded that this current is the only possible source for the observed warm water, which is progressively mixed as it moves northward and eastward. It is notable that in the present investigation, the surface water temperature at Stns 76, 58, 42 and 20 near the Greenland coast displayed a progressive decrease of $0.6,0.5,0.4$ and $0.3^{\circ} \mathrm{C}$, respectively, from south to north (Figs. $1 \& 2 \mathrm{~B}$ ). This pattern could indicate that, in fall, there is a northward current, probably the WGC, crossing the NOW which follows the Greenland coast. This agrees with the surface dynamic topography proposed by Bourke et al. (1989, their Fig. 4).

The presence of another group of picophytoplankton, the picocyanobacteria, in warmer waters in the Arctic region (in the ice-covered East Greenland current at $80^{\circ} \mathrm{N}$ in the Greenland Sea) has already been demonstrated by Gradinger \& Lenz (1989). They found that within the upper $200 \mathrm{~m}$ of the water column, picocyanobacteria abundances decreased from the warm Atlantic Intermediate Water (AIW) to the cold Polar Water (PW). Gradinger \& Lenz (1989) indicated that the number of cyanobacteria was extremely low in the East Greenland Current (EGC) area, where eukaryotic phytoplankton constituted the main fraction of picophytoplankton. The main current in the East of Greenland is the southward EGC. This current, at the southern point of Greenland (Cape Farewell), flows north and joins the Irminger Current (North-Atlantic Water). This current then follows the Greenland coast and constitutes the WGC, which enters Baffin Bay (Tchernia 1978, Clarke 1984). It is therefore possible that seed population of picophytoplankton could be advected in the surface waters of Baffin Bay and eastern region of the NOW by WGC, waters already conditioned for successful growth of picophytoplankton.

In summary, the results of this study show that picophytoplankton can be used to distinguish the origin of the 2 major surface water masses in the NOW during the fall of 1999. Indeed, the colder, less saline, Arctic surface waters originating from the Kane Basin, which move southward along the Canadian side of the NOW, contain very few picophytoplankton, whereas the warmer, more saline, surface waters originating from WGC, originating from Baffin Bay and progressing northward along the Greenland side of the NOW, favor the growth and accumulation of picophytoplankton. 
Acknowledgements. This research was supported by grants from the Natural Sciences and Engineering Research Council (NSERC) of Canada to M.G., Y.G. and S.D. We are grateful to the Polar Continental Shelf Project and the Canadian Coast Guard officers and crews of the CCGS 'Pierre Radisson' for their skillful support during the expedition. We are especially indebted to Louis Fortier (chief scientist) and Martin Fortier (scientific coordinator) for their leadership, to Captain Richard Dubois and all officers for their extensive cooperation, to Marcel Gagnon and his team for their logistic support, and to Roger Tardif and his team for serving excellent meals onboard the ship. We thank Dr Jody Deming for preservation samples for phytoplankton microscopic indentification; Dr Suzanne Roy for use of her HPLC; Dr Bert Klein for providing size fractionated chl a data; Bryan Weissenboeck for improving the English; and Dr Evelyn Sherr and 2 other anonymous reviewers for useful suggestions. This is a contribution to the research programs of the International North Water Polynya Study and the Institut des sciences de la mer de Rimouski.

\section{LITERATURE CITED}

Addison VG Jr (1987) Physical oceanography of the northern Baffin Bay - Nares Strait region. Masters thesis, Naval Postgraduate School, Monterey

Booth BC, Horner RA (1997) Microalgae on the Arctic Ocean section, 1994: species abundance and biomass. Deep-Sea Res II 44:1607-1622

Booth CB (1993) Estimation cell concentration and biomass of aquatic plankton using microscopy In: Kemp PF, Sherr BF, Sherr EB, Cole JJ (eds) Handbook of methods in aquatic microbial ecology. Lewis Publishers, Boca Raton, p 199-205

Booth CB, Smith WO Jr (1997) Autotrophic flagellates and diatoms in the Northeast Water Polynya, Greenland: summer 1993. J Mar Syst 10:241-261

Bourke RH, Addison VG, Paquette RG (1989) Oceanography of Nares Strait and Northern Baffin Bay in 1986 with emphasis on deep and bottom water formation. J Geophys Res 94:8289-8302

Carpenter EJ, Guillard RRL (1971) Intraspecific differences in nitrate half-saturation constants for three species of marine phytoplankton. Ecology 52:183-185

Clarke RA (1984) Transport through the Cape Farewell-

Editorial responsibility: William Li,

Dartmouth, Nova Scotia, Canada
Flemish Cap section. Rapp P-V Réun Cons Int Explor Mer 185:120-130

Eppley RW, Rogers JN, McCarthy JJ (1969) Half-saturation constants for uptake of nitrate and ammonia by marine phytoplankton. Limnol Oceanogr 14:912-920

Gradinger R, Lenz J (1989) Picocyanobacteria in the high Arctic. Mar Ecol Prog Ser 52:99-101

Legendre L, Legendre P (1984) Écologie numérique, Vol 2: La structure des données écologiques, 2nd edn. Masson, Paris

Lewis EL, Ponton D, Legendre L, LeBlanc B (1996) Springtime sensible heat, nutrients and phytoplankton in the Northwater Polynya, Canadian Arctic. Cont Shelf Res 16: 1775-1792

MacIsaac JJ, Dugdale RC (1972) Interactions of light and inorganic nitrogen in controlling nitrogen uptake in the sea. Deep-Sea Res 19:209-232

Melling H, Gratton Y, Ingram RG (in press) Oceanic circulation within the North Water Polynya in Baffin Bay. Atmos Ocean

Muench RD (1971) The physical oceanography of the northern Baffin Bay region. Baffin Bay-North Water Project Report No. 1, Arctic Institute of North America, Montreal

Parsons TR, Maita Y, Lalli CM (1984) A manual of chemical and biological methods for seawater analysis. Pergamon Press, Toronto

Redfield AC, Ketchum BH, Richards FA (1963) The influence of organisms on the composition of sea-water. In: Hill MN (ed) The sea, Vol 2. Interscience, New York, p 26-77

Sokal RR, Rohlf FJ (1981) Biometry-the principles and practice of statistics in biological research, 2nd edn. WH Freeman and Company, San Francisco

Solórzano L (1969) Determination of ammonia in natural waters by the phenolhypochlorite method. Limnol Oceanogr 14:799-801

Steffen K (1985) Warm water cells in the North Water, northern Baffin Bay during winter. J Geophys Res 90:9129-9136

Steffen K, Ohmura A (1985) Heat exchange and surface conditions in North Water, northern Baffin Bay. Ann Glaciol 6: $178-181$

Strickland JDH, Parsons TR (1972) A practical handbook of seawater analysis. Bull Fish Res Board Can 167

Tchernia P (1978) Océanographie régionale. Description physique des océans et des mers. École nationale supérieure de techniques avancées, Paris

Submitted: July 14, 2000; Accepted: November 14, 2000 Proofs received from author(s): January 9, 2001 